\title{
Parodies of the Past, Fears of the Future: The Failure and Triumph of Storyline in Don Delillo's Trauma Narratives
}

Alaa Alghamdi*

Taibah University, Saudi Arabia

Corresponding Author: Alaa Alghamdi, E-mail: alaaghamdi@yahoo.com

\section{ARTICLE INFO}

Article history

Received: September 07, 2019

Accepted: November 10, 2019

Published: December 31, 2019

Volume: 10 Issue: 6

Advance access: December, 2019

Conflicts of interest: None

Funding: None

Key words:

Delillo,

White Noise,

The Falling Man,

9-11, Traumatic State,

Gilles Deleuze

\begin{abstract}
Though Don Delillo's writing spans the period before and after September 11, 2001, consistent themes emerge. Such themes unite an early novel, White Noise, and The Falling Man, one of the definitive American novels about the events and aftermath of 9-11. In each, the characters experience a loss of connection with other people and with the real settings and circumstances of their lives. This leads to a breakdown of journey and storyline, where past and present merge and resolution cannot be reached. The fact that this mentality exists in both narratives, written before and after 9-11, suggests that the tragic events of that day did not create the mental devastation that followed, but that it was pre-existing. In an effort to characterise that state, comparisons are drawn to literary antecedents including Tennyson's poem "The Lady of Shalott" and the story of the Fall of Man (suggested by the title of Delillo's novel). In addition, concepts from psychology and philosophy are utilized, including but not limited to psychological and philosophical concepts of repetition, modern 'simulation theory' and Gilles Delueze's observations regarding non-linear time. This paper concludes that the lack of connection with the human, physical and historical worlds brings about an alienation that causes one to predict and even pre-experience trauma, and this 'pre-traumatic' state, in turn, prevents connection and perpetuates the very loss that one dreads.
\end{abstract}

\section{INTRODUCTION}

Don Delillo's publication in 2007 of one of the definitive American novels expressing the experience of $9 / 11$ had been expected and anticipated, according to Toby Litt of The Guardian. Long before The Falling Man and the events that inspired it, Delillo was known for his apt expression of the American psyche in a time of crisis. Of all writers, Delillo "came closest to prefiguring, if not predicting, the attacks on Washington and New York... so even as news of those attacks was received, Delillo's was the name that came to mind (Litt).

In considering the thematic similarities and historical developments in two of Delillo's novels, The Falling Man (2007) and White Noise (1985), a coherent picture emerges. Delillo argues that it is the way life is lived in the modern world, the fault lines already appearing, that has led to the fractured narrative and incoherent identities depicted in The Falling Man. At the same time, the present participle in the title indicates something in progress at this time. He is falling and not fallen, which indicates continued suffering as much as it suggests a faint hope that the cycle may be broken.

White Noise does not centre around any single cataclysmic event, real or fictional; what is remarkable, however, is the pervasiveness of an ongoing sense of doom - a slow-motion 'fall'. Protagonist and narrator Jack has been exposed to a lethal chemical that lasts in the human body for 30 years; in half that time, he will be given a definitive answer regarding his chances for survival. In the meantime, although he remains healthy, he knows that the possibility of his death is already within him, and that cannot be reversed. In both novels, then, the concept is one of impending doom and the accompanying dread, and as White Noise demonstrates, this proves potentially debilitating even in the absence of problems in the present.

This fear of the absence of a future is common in the social history of the post-World War II period in the West. During the Cold War era, there was a fear that bordered on certainty that a nuclear holocaust would bring about an end to civilization as we know it. School children as young as five years old were taught to "duck and cover" in case of a nuclear attack ("Nuclear Protection"). The gradual receding and eventual end of the Cold War in the late 1980s did not inevitably lead to optimism, however, as other worries clouded that view. Today, justifiable concerns regarding the environment and the human effect on it cloud the view of the future. Today, 'birthstrikers' refuse to have children because of the perils of climate change, a powerful statement regarding lack of hope for the future (Woodward). All of these factors make Delillo's work highly representative of the 
mentality and outlook of people in the West during the last several decades, or at least of one key thread in that outlook. Pessimism about the future is not, however, merely a result of circumstances, but a cause of increased disconnection from one's surroundings, which in and of itself injures the psyche and causes fear - at least, this is what a close reading of the commonalities in Delillo's two novels suggests.

There can be no doubt that the events of 9-11 left a particular scar upon the American mind and heart, one from which recovery is slow and uncertain. Yet what is striking about the works of Delillo is the continuity within the psyche of the characters before and after this catastrophe. It is possible that 'falling' described in The Falling Man had already begun decades before planes crashed into New York's Twin Towers and, in desperate response, people jumped to their deaths. In fact, Delillo both implicitly and explicitly makes a case for the inclusion of preceding events and circumstances in the experience of 9-11. As a character in The Falling Man states, figuratively more than factually, "Eight years ago they planted a bomb in one of the towers. Nobody said what's next. This was next" (Delillo TFM Chapter 2). Even in the absence of conspiracy theories about the attacks, there is a strong and important psychological truth to this notion of one's doom being pre-orchestrated, preordained: the notion, in short, of having been cursed.

What truly knits together the psychological states of the characters in White Noise (1985) and The Falling Man (2007) is a sense of the inevitability of a disaster or fall. In essence, this is an experience of being cursed, or feeling that one is (an important distinction). To contextualize such a concept, comparisons abound in Western culture, from current popular psychology all the way back to the 'fall of man' in the Genesis Biblical story of the Garden of Eden. With references to these depictions of The Fall, and allusions to an intermediary example, Alfred, Lord Tennyson's poem "The Lady of Shalott", it will be argued that Delillo in The Falling Man is in not in fact describing a new phenomenon that suddenly occurred less than twenty years ago as a result of a terrorist act. Rather, he describes a state of mind which was neither the cause nor the effect of the events of 9-11, but incorporated these events as a perfectly logical, even expected adjunct to and culmination of what was already the state of the Western psyche - a state of foreboding and anxiety, both creating and resulting from disconnection with the human, historical and social reality and the possibility of an intact storyline. In some cases, the disconnection is so profound as to create a persistent sense of an alternate, artificial world.

\section{THE FALL}

The story of a Fall from grace is archetypal, the foundational story that underlies not only western civilization through the Biblical Book of Genesis, but also all three Abrahamic religions. As a result, it forms the framework for the psyche of a generous proportion of the world's people. The story itself is simple: through disobedience, humans were removed from the physical context in which they were intended to thrive. This loss was permanent, or nearly so; it can only be remedied at the end of the world as we know it, through divine intervention. Because of this Fall, we are cursed. We wander the earth with no true sense of belonging in it and to it. We have lost not only immortality and painlessness, but also our once intimate connection with the divine, the essence of love.

Through it deals with the aftermath of a terrible human tragedy that occurred in our lifetime, it may be significant to note that Delillo's post-9-11 novel, while sharing elements of the 'fall' story as delineated above, is not quite as pessimistic. In it, man is not 'fallen' as the biblical version states, merely 'falling', at present. Yet in White Noise as well as The Falling Man, elements and ramifications of a Fall are repeatedly enacted.

There is no shortage of subsequent literature, from the West and beyond, that describes elements and echoes of that same Fall. From the vast cornucopia for such, for purposes of comparison with Delillo, Alfred, Lord Tennyson's "The Lady of Shalott" has been chosen. Written in 1833, it is a variation on the themes of the Fall, the impossibility of connection, fear for the future, and most of all, isolation, that may be considered prescient of the $21^{\text {th }}$ century despite (or perhaps because of) its simple and dreamlike storyline.

These are the elements of the narrative (for the full poem, see Appendix 1):

For reasons unknown, a beautiful lady has been imprisoned in a tower. However, contrary to the fairy tale trope, she is not awaiting rescue from a prince or lover, and her very hope for such connection is her demise. While in the tower, she is not idle, but has a task to complete: observing outside events through her mirror (for she must not look directly outside) she has to weave what she sees into a tapestry. If she seeks more direct experience with the outside world - for example, by looking directly through the window - she will call down a curse that has been put upon her, one that she does not know the nature or source of. A 'whisper' has told her that it is the case. This whisper is sufficient to imprison her.

Yet the Lady of Shalott does rebel. "Sick of shadows", she dares to look directly out her window, where she sees Sir Lancelot and (in a gender reversal of the courtly tradition) is instantly infatuated enough to risk her cursed life to pursue him.

Unfortunately, this ends quickly and badly. At the moment of her rebellion, her mirror cracks and her tapestry flies from the window - elements of her previous world are lost to her. She recognizes these as signs of the curse having come upon her, and, knowing her death is impending, floats down to Camelot in a boat. By the time she gets there, she is dead, the curse having put a quick end to her without the necessity of logical or biological causes. As a final irony, Lancelot carelessly blesses her, noting she has a lovely face, but feeling nothing for her.

This simple narrative is also a failure of narrative, in that there is no true plot of the sort commonly illustrated by Freytag's pyramid. The death of the Lady of Shalott is tragic, and bewildering, but not truly compelling as she puts up no fight. She is not even a tragic heroine according to the conventions of Aristotle - she has no fatal character flaw, unless it is the curse itself. Had curiosity not impelled her to chal- 
lenge her fate, she would still have been cursed and devoid of narrative. No discoveries are made except that the thing she has always feared turns out to be true. She shows some courage in turning away from the authority of the 'whisper', but there is no battle, no small triumph, no climax or denouement, and nothing of value being brought back to society. Perhaps the lesson is that she is no hero and should not have been answering any such call. She simply dies - "not with a bang but a whimper", to borrow from another poet ${ }^{2}$ - and that is the end. What is relatable and haunting about the Lady of Shalott's "story" is her isolation and its reason, the rumoured but unnamed "curse" which turns out to be all too true.

The Lady of Shalott, once considered a metaphor for the necessary isolation of the artist (Alaya 273), is eerily relevant today in a world where impressions of people and events come to us second-hand, through a personal screen that is also one's means of interacting. It also has undeniable but ambiguous parallels to the story of the original Fall, parallels which perhaps indicate, as Delillo does as well, that once fallen, one continues to fall.

The Lady's original state - imprisoned, disconnected from the world, mortal, and afraid - epitomises life outside of the Garden of Eden. Indeed, the green world she longs for, the idyllic Camelot, is exactly what she is excluded from, like humans are excluded from the garden that reputedly gave us true and eternal connection. She is hidden, which implies shame, also a characteristic of the fallen state. Finally, her death is impending, proof that she exists separated from eternal life.

On the other hand, it is also in accordance with the theological story to observe that her tower is a kind of Garden of Eden for her, and only in disobeying and leaving it does she fall. Alaya interprets that she is in a state of artistic dedication or "priestcraft", for which isolation is necessary (273). In fact, this latter interpretation matches the storyline much better; she was in an idealised (through her artistic depiction of events) and protected state, but her temptation to do what she has been told not to do (albeit by a 'whisper') - her temptation for connection or perhaps for a romantic encounter - dooms her, expels her from her sanctuary. Her journey down to Camelot, dying, is then her Fall.

In truth, it is impossible and unnecessary to choose between these two interpretations of the Lady of Shalott story as a Fall, because collectively they show that falling is continuous. We are fallen - mortal, fearful, vulnerable, disconnected - and so, as a result, we fall. As a result of that fall we are again fallen. And so on. The perfect way to express this is Delillo's use of the present participle in this title - the Falling.

These same narrative and thematic elements are present in both White Noise and The Falling Man. Indeed, "The Lady of Shalott" may give us a sort of early blueprint to better understand the concerns of the characters and the desultory plot of both novels. Specifically, the elements that both novels share with Tennyson's poem consist of:

- The presence of a 'curse': that inevitably, because of a seed planted in the past, something terrible will happen in the present or future.
- Isolation from others, present and past - a failure of human connections and relationships.

- Existence within artificial, simulated environs in which reality is mediated or somehow given an unreal quality.

- A failure or absence of traditional plot or storyline.

It is perhaps the quality of impending doom - the sense of an indeterminate curse, as it were - that resonates so strongly with a reading public who either remember the Cold War and impeding nuclear holocaust, or were raised in its aftermath. It is remarkable, in comparing Delillo's two novels, where the sense of impending harm is so similar in both, despite the fact that The Falling Man was written after the sky had fallen, so to speak, and deals directly with that falling. The event itself has made less difference than one might suppose.

\section{"SHE HAS HEARD A WHISPER SAY/ A CURSE IS ON HER IF SHE STAY": THE PRE-TRAUMATIC STATE}

Both Delillo novels are populated primarily by a family, and both families share a sense of being cursed. This is more readily apparent in White Noise, where there is a constant fear for the safety of the children, culminating in an actual, impending, though uncertain crisis. However, in The Falling Man, which in a way represents a later stage of events - after the curse has fulfilled itself - there is a reference to the idea that they had known all along something devastating would happen. So when the devastating event does come, though it is a shock, it is not a complete surprise. Rather, there is a sense of recognition - Nina's statement, "This was next" (Delillo TFM chapter 2).

Jack's family in White Noise are fairly dominated by fear - the fear that comes from living in a modern society alongside technology and potential contamination. A key plot point is Jack's exposure to the chemical Nyodene D, and he will know in years to come how or whether he has already been affected by it. In the meantime, however, fear already permeates the family life and relationships within the story, impairing Jack and Babette's relationship as she commits adultery to obtain a drug promising to diminish fears of dying. The sense of impending pain or devastation, its vehicle uncertain but its eventual arrival inevitable, has much in common with the concept of a curse. Most importantly, both work in delayed-action; one may know that one is cursed without currently feeling any of the effects. One knows, moreover, that the curse sets one apart, barring one from the easy participation in life and hope for the future enjoyed by much of the population.

When a curse comes from a discernible source, as is customary in certain fairy tales, one may set to work bargaining or outsmarting the source in order to remove it. But when the reason or source is uncertain, there is no one with whom to bargain, and in that absence there is a vague sense of self-blame. Bringing down the curse upon oneself follows disobedience or other wrongdoing, perhaps a reflection of the Christian concept of Original Sin, acquired in the original Fall. The fact that it spans time, connecting past (the cursing), present (living with an impending curse) and future (doomed by the curse), suggests the presence or per- 
sistence of elements through time and underlines the lack of possibility of escape. But that a future doom is so palpably present in the here and now - present to the point that it defines one's existence even prior to being acted out - calls to mind Gilles Deleuze's concept of "curtains of time". In Deleuze's 1968 work entitled Difference and Repetition, he describes a concept of time not as a line but as a series of curtains hanging parallel to one another. One can be drawn back to reveal another, to catapult the subject suddenly into a different reality and set of circumstances. The idea of a curse being irrevocable is somewhat relieved by this model - if we choose something different, it may not fulfil itself. However, given that the curse threatens to drastically change or do away with what is precious in our current reality; curtains of time are also consistent with the threat of a curse, or of loss in general. In any case, the notion of curtains of time is antithetical to that of a stable and continuous reality. Moreover, within this model, the past is never left behind, and the future already exists.

"Listen. Billy Pilgrim has come unstuck in time" - this is perhaps the most famous line of Kurt Vonnegut's famous novel Slaughterhouse Five, a fantastical but perfect rendition of a WWII veteran suffering from what is now known as Post Traumatic Stress Disorder or PTSD (Vonnegut Chapter 2). The term had not been coined yet when Vonnegut wrote the novel, but the symptoms are clear; after witnessing the bombing of Dresden, Billy Pilgrim fails to fully rejoin everyday life. In diverse ways, he is constantly drawn back to the time and scene of the trauma. It is like that particular time has a stronger magnetic pull than any other. It creates a vortex into which the stream of his life is drawn, disrupting the orderly progression of days, months and years after the event. Instead of flowing smoothly and linearly, the timeline of his life is warped, pulling back to the event that once ruined it. Plot necessarily becomes non-linear, as an orderly chronology can neither describe nor survive the pull of the central traumatic event.

Much more is known nowadays of this condition that was once called shell shock and thought to be limited to war veterans. PTSD affects one's sense of rootedness in present reality, constantly drawing one back toward an earlier time, a trauma that was both devastating and key to one's emotional life. Freud referred to these "traumatic reenactments" as "the compulsion to repeat" (cited by van der Kolk, 1989). As Bessel van der Kolk explains in his comprehensive volume on the effects of trauma on the brain and body, traumatic experiences and the memory of such can shut down the functioning of the prefrontal cortex, which is responsible for our sense of time and context (44). In effect, trauma may destroy our sense of both time and identity. It is a psychological condition that may well be at play in the characterisations in The Falling Man, much as it affects thousands of survivors and emergency response volunteers who witnessed 9-11. Indeed, like Vonnegut's Billy Pilgrim, Keith in The Falling Man experiences the loss of both identity ${ }^{3}$ and timeline, as the conclusion of the novel has him back where he started, bloody and escaping the scene of the Twin Towers' fall.

However, I would argue that the characters in White Noise are suffering from a similar, perhaps parallel condition, despite the fact that they have not yet suffered any significant trauma. They exist in expectation of it and this, like PTSD itself, affects their ability to relate to the real world that surrounds them. Instead of functioning within the external world and forming relationships with it, they are consistently pulled to an experience of an fatal and inescapable trauma - one that they have not yet experienced. I would like to refer to this as a 'pre-traumatic' state, acknowledging that, unlike the term and reality of a 'postraumatic' condition, this is not a psychological term. Instead, it is an attempt to explain and characterise a worldview dominated by the expectation of disaster - someone, in short, who feels themselves to be cursed.

As it has in numerous other times in history, the pre-traumatic condition has become endemic to Western society. Aside from the many folktale and literary examples of characters who, like the Lady of Shalott, know that they are cursed and that they will one day (soon) fall victim to the force that has been stalking them all their lives. Perhaps the omnipresence of the pre-traumatic state suggests that there is something in the human psyche that seeks it out and possibly even prefers it. After all, with insoluble problems in the impending future, one is relieved from seeing to the present. Psychologist and researcher Brene Brown suggests another possible reason. In her TedX Talk "The Price of Invulnerability", Brown describes a state in which people in our society today become intolerant to the vulnerability that occurs with negative or positive emotions. To mitigate the sense of vulnerability one automatically imagines a horrific scenario occurring, shattering the peace and happiness one currently experiences. Happiness itself becomes a trigger for imagining a loss of that happiness. In essence, one perceives oneself as cursed, unable to attain a feeling of peace, love and wellbeing without courting or bringing about the opposite. Brown explains:

How many people I've interviewed who will say 'I'm looking at my children and they're sleeping and I'm on this verge of bliss and I picture something horrible happening... I get the promotion and I get to fly up to headquarters... to find out about my new job and what happens, plane crashes. The fatalistic response is not universal. But it is a symptom of an issue that is both universal and I believe profoundly dangerous. And that is, we are losing our tolerance for vulnerability. (Brown, TedX, The Price of Invulnerability)

Brown goes on to explain that this morbid focus on negative outcomes keeps one from being in the present and engaging closely with the blessings in one's life. This feeling of foreboding may also contribute to a 'pre-traumatic' state, the absence of a negative event becoming strongly associated with the dread of such an anticipated event. This is the state that Delillo's characters in White Noise exist within. And as Brene Brown implies, perhaps its most characteristic element is that loss or avoidance of connection with the present, immanent reality.

\section{SHADOWS OF THE WORLD - SIMULATION AND ISOLATION}

In recent years the idea that we might be living in a simulation has become popular, even amid intellectual circles. 
Most famously, Tesla CEO and Chief Engineer Elon Musk has stated publicly that "we are most likely in a simulation... I think most likely - this is just about probability - there are many, many simulations. You might as well call them reality, or you could call them multiverse" (Wall). In a simulation, all of our perceptions are controlled by an ulterior intelligence and brought to us through technology. Articles have been published Scientific American and Cosmos outlining, evaluating and critiquing this idea. In short, the notion, which at first glance appears to be part sci-fi and part paranoid delusion, is one that is currently permeating society rather than being confined to a lunatic fringe. Of course the idea itself is hardly new. In his Meditations on First Philosophy (1641), Rene Descartes entertains the possibility that our perceptions are being created and controlled by an 'evil demon' and he embarks on an elaborate philosophical argument to discover that God, rather than this evil magician, is actually in charge of what we see around us.

Of course, the notion of a simulation, barring religious faith, cannot be proven. What is important to the present argument, however, is the compelling nature of this hypothesis. A simulation is by definition an artificial version of reality. It is a manipulation and an illusion. In short, to believe that we are living within a simulation is to believe that the world around us is not real.

In her tower, the Lady of Shalott at least knows for certain that the stimuli she encounters, and then transcribes on her "magic web", are not reality. They are "shadows of the world", indirect experience. This is, of course, an element of her curse; if she looks away from the mirror that feeds her the images and seeks the reality beyond, she will die. An artificial setting is a repetition of what one observes in reality. On her loom, the Lady of Shalott recreates what she has observed in the larger world, which in itself is a copy that she sees in her mirror. Yet when it comes time for her to leave her pattern and embark on a voyage into the real world, seeking connection with Lancelot, the whispered curse catches up with her and she expires on her journey. Her storyline fails along with her. The quest - in this case, a brave and romantic quest - ought to be the start of a journey, followed by hardships to be overcome and a final return to one's home with something of value. For the Lady of Shalott, the first act of this universal tale is also the end. Her quest, in short, is not the only thing that fails - her storyline does as well.

Both White Noise and The Falling Man deal extensively with social and cultural environments that are largely artificial, shadows or echoes of authentic experience or relationship made from shattered, reconstituted and caricatured elements. History and social institutions, beginning with the family, are subtly manipulated, so that, looking at them through a skewed lens, we naturally doubt their ultimate reality. Much like the Lady of Shalott's mirror and magic web reproducing shadows of the world, Delillo's distancing of his characters from reality through their reconstitution and caricature has a protective effect: if the world is not actually, ultimately real, we do not fear the end of it as much as we otherwise might. At the same time, however, we are experiencing the loss of it constantly as we are unable to fully connect with it. Storyline disappears or becomes fragmented along with connection so authentic resolutions can no longer be reached.

The Falling Man illustrates this isolation within family brilliantly by reconstituting a shattered family unit so that that appearance of it remains, but not the reality. By the same token, Keith doubts his own reality. At the beginning of the narrative, having just experienced the falling of the towers, Keith "tried to tell himself he was alive but the idea was too obscure to take hold" (Delillo TFM 6). This is the loss of identity and a sense of reality at its most basic. As the first chapter closes, we find him "... going back to where... he was going all along”. However, we soon find him living in a mere artificial version of the family he once had. Though they come together and his presence is tolerated, Keith does not find himself in the midst of an intact family again merely an emotionally empty reconstruction of one.

Keith is accepted back into Lianne's home, but it is clear that he has not resumed his previous position there. There may be love between Keith and Lianne, but there is not partnership - rather, he is an object of worry, consternation and pity. What has been broken cannot be put back together easily, and the version of it that remains in the aftermath is simulated.

In White Noise, isolation and simulation are suggested through the use of distancing language which makes it clear that the narrator, though part of the human world that he describes, profoundly objectifies what is happening around him and ostensibly concerns him. In the opening chapter, Jack, a university professor, watches the influx of students on the first day of class:

It is a brilliant event, invariably. The students greet each other with comic cries and gestures of sodden collapse. Their summer has been bloated with criminal pleasures, as always. The parents stand sun-dazed near their automobiles, seeing images of themselves in every direction. The conscientious suntans. The well-made faces and wry looks. ... this assembly of station wagons, as much as anything they might do in the course of the year, more than formal liturgies or laws, tells the parents they are a collection of the like-minded and the spiritually akin, a people, a nation. (Delillo WN Chapter 1).

There is a tangible sense of mocking in these words, as well as the objectification necessary to maintain it; as though the assembly of students and parents is a phenomenon that Jack is totally unconnected with but is observing with an academic and aesthetic interest and some derision. It is inconceivable from this description that he would join or feel himself a part of this crowd. As the description continues, Jack brings the reader physically closer to his own home and family, but the objectivity is maintained through juxtaposition and references to assorted times, cultures and styles:

I left my office and walked down the hill and into town. There are houses in town with turrets and twostory porches where people sit in the shade of ancient maples. There are Greek revival and Gothic churches. There is an insane asylum with an elongated portico, ornamented dormers and a steeply pitched roof topped 
by a pineapple finial. Babette and I and our children by previous marriages live at the end of a quiet street in what was once a wooded area with deep ravines. (Delillo WN Chapter 1)

Jack introduces the human elements of his life and immediately backs away from close association with them. His and Babette's children, for example, are not merely their children but their "children by previous marriages". Their home is not merely their home; there is an immediate reference to what it used to be before it was that. Jack's most unequivocal statement about his identity is made with regard to his job - "I am chairman of the department of Hitler studies at the College-on-the-Hill" (Delillo WN Chapter 1). He hastens to add "I invented Hitler studies in North America in March of 1968 ", demonstrating that this bulwark of his life was his own creation, and the college he teaches at is never given a more solid reality by virtue of a real (or real-fictional) name (Delillo WN Chapter 1). In fact, Delillo, through Jack, excels at naming and labelling things in such a way that their artificiality is highlighted. Of course, it later becomes apparent that this is part of his job:

The chancellor had advised me, back in 1968, to do something about my name and appearance if I wanted to be taken seriously as a Hitler innovator. Jack Gladney would not do, he said, and asked me what other names I might have at my disposal. We finally agreed that I should invent an extra initial and call myself J.A.K Gladney, a tag I wore like a borrowed suit. (Delillo WN Chapter 4)

In addition to adjustment to his name, Jack is advised to wear black-rimmed glasses and even to put on weight. He is aware that his professional persona is contrived, commenting, "I am the false character that carries the name around", but does not seem aware of an identity beyond this contrived one (Delillo WN Chapter 4). Moreover, he takes for granted the validity of such terms as 'Hitler innovator', which one suspects to be satirical and yet which necessitates his transformation.

As chair of the celebrated department of Hitler Studies - his own invention - Jack has achieved a sort of commodification of a horrific era of the not-very-distant past. Despite his lack of authentic knowledge - exemplified by his shame at not knowing German - the 'packaging' of history in this manner is successful. It is also, of course, eminently artificial or simulated. There is, of course, a measure of satire in Delillo's invention of Hitler Studies at "The College on the Hill". But as with all good satire, one is invited to look to the real-life equivalents that are, perhaps, being exaggerated so that they might be exposed and examined. Hitler Studies represents a trivialization of the past, particularly tragic eras of the past, for the edification or entertainment of those in the present. This is undertaken without sufficient regard for the actual complex circumstances that brought about the events of that time period - again, as demonstrated by Jack's ignorance of German. (True, during the course of the novel, he is engaged in learning German - this and his own shame regarding his ignorance showing a striving toward something more authentic). Thus the past becomes a simulated version of itself - shallow, contrived, commodified, and thus knowable and predictable. Nuggets of 'knowledge' have been taken from the culture of that time, which may or may not be authentic.

Perhaps it is inevitable that history, which one can never really know firsthand, exists as an artificial or simulated version of itself. However, the artificiality extends to the present time in which the characters live. Jack's son Heinrich's name is clearly done in homage to Jack's academic interest, as the family has no actual ties with Germany. And it is through Heinrich that we acquire the most striking ideas and perceptions regarding the artificiality of life, though Heinrich does appear to be speaking for all of them, perhaps carrying the ideas he already finds in his upbringing to their fruition. Through his ideas and his name, displaced from history and geography but perfectly expressing his origin as his father's son, Heinrich is as near as we have to a simulated, perhaps artificially reconstituted person. At the same time, however, his seeming belief in a simulation may only be a representation of his fear. Whereas Jack seems aware of and perhaps disturbed by the air of slight unreality his life and work takes on, Heinrich clearly articulates a distancing from empirical reality. In one scene, where Jack is driving Heinrich to school and remarks on the weather, Heinrich will not believe that it is raining despite seeing rain on the windshield. He repeats what the radio has said, that it would rain that night. Jack remarks, "Just because it's on the radio doesn't mean we have to suspend belief in the evidence of our senses".

Heinrich, who is 14, responds with a statement that anticipates simulation theory, carrying Jack's own disconnection with his immediate surroundings much further:

'Our senses? Our senses are wrong a lot more often than they're right. This has been proved in the laboratory. Don't you know about all those theorems that say nothing is what it seems? There's no past, present or future outside our own mind. The so-called laws of motion are a big hoax. Even sound can trick the mind. Just because you don't hear a sound doesn't mean it's not out there.

Dogs can hear it. Other animals...'

'Is it raining,' I said, 'or isn't it?'

'I wouldn't want to have to say.'

The reasons for Heinrich's seeming belief in the artificiality of human and social existence is strongly implied: his parents both have unstable or artificial identities - Jack's persona as the chair of Hitler studies as described above, while:

Heinrich's mother lives in an ashram now. She has taken the name Mother Devi and runs the business end of things. The ashram is located on the outskirts of the former copper-smelting town of Tubb, Montana, now called Dharmasalaspur. (Delillo WN Chapter 6)

Heinrich's radical disbelief in the evidence of his senses regarding the world around him is extreme and unsettling. One worries about the boy and his sense of reality, wondering how he will be able to function in this world that he does not wholly believe in. And yet it is evident that his schema (his view of the world and way of making sense of it) is congruent with the layers of artificiality obscuring everything about his surroundings, from his father's invention of Hit- 
ler Studies to his mother's role in a renamed and culturally displaced ashram, to his own first name, given his lack of German heritage. Yet it is clear also in these scenes between Jack and Heinrich that there is something very real and authentic, albeit fearful, in their connection. Following the aforementioned conversation with Heinrich, Jack confesses, "At such moments I find I love him with an animal desperation, a need to take him under my coat and crush him to my chest, keep him there, protect him" (Delillo WN Chapter 6).

Here and elsewhere in his own self-observations, Jack admits to feeling a fear bordering on desperation when he considers his children and his love for them. A passage a few chapters later describes what appears to be an anxiety attack upon waking:

I woke in the grip of a death sweat. Defenceless against my own racking fears. A pause at the centre of my being. I lacked the will and physical strength to get out of bed and move through the dark house, clutching walls and stair rails. To feel my way, re inhabit my body, reenter the world (Delillo WN Chapter 11)

Yet it is the last words of both the above quotes that are so telling. In feeling the fear for himself and his family, Jack struggles to 'reenter the world', as though the fear is keeping him from it. We know, of course, that he is alive, cognizant and awake, so 'reentering the world' conveys an emotional state, a willingness to partake of the uncertainty and possible loss that might come from his participation in the world. It also implies that there is an option, or perhaps an impediment - in the grips of anxiety, Jack is, not, in that moment, 'in the world' or even in his body. The force of his fear has made him dissociate or detach from it, as though for his own protection.

Protection, of course, is the key concept. In the earlier quote, in his desperation to protect Heinrich, Jack wishes to hide him away from the world. Nevertheless, this impulse is incongruous with the Heinrich we have just been introduced to - precocious and cynical, not willing to believe even the evidence of his eyes that it is raining. The delusion of his beliefs (or lack thereof) may indeed make Heinrich seem vulnerable, but the seeming sophistication of his argument belies this. It is just possible that the whole disbelief in the world that Heinrich courts is both the legacy of his parents' shifting identities and a protection in and of itself. Jack wishes to protect Heinrich in his coat like one would with a very small child, but this is impracticable; instead, Heinrich's partly inherited, partly self-constructed worldview offers protection of its own. If the world around him is possibly unreal, if his own senses cannot be believed, it is harder for him to be hurt.

Within a simulation, only shadows of the world appear - or, conversely, the world is shadows, artificial imprints of something once thought real. It is experience removed by one or two or three degrees, so that what is delivered to us (via some sort of information feed) does not any longer elicit much concern or indeed any genuine emotion, but merely a second-hand experience of such. Sometimes not even vicarious emotion is produced, but a detachment that is probably natural when one does not believe in the ultimate reality of what is being presented. One exists behind a buffer and is offered illusions, the true nature of existence being hidden and inaccessible. Of course, if one seeks escape from anxiety through the loss of feeling that results from believing nothing around us is real, one ultimately fails; behind the simulation hypothesis is the acute fear that, if this is all manufactured, it may suddenly end. In essence, we have a familiar paradox; we are detached from the world around us (because it may not be real), but terrified of losing it (also, because it may not be real, increasing the possibility that someone will arbitrarily end it). Disconnection and fear of impending loss are also the hallmarks of that same 'pre-traumatic' state described previously. Belief that the world is a simulation, or acting as though it is, is therefore a catch-22; it can provide an excuse for not caring, but only if all hope of deep connection is severed, which is the essence of fears of loss. In other words, the loss that one fears is perpetrated by oneself.

In this way, the slightly simulated reality occupied by Jack, Babette and their children isolates and appears to protect them from the precarious world around them - but at great cost. They are likewise insulated from the only thing that could end their vague and constant alienation - true and deep connection with one another.

The loss of such connection is hurtful perhaps because the remnants of such connection exist. Jack's family is not devoid of love, but familial relationships are expressed in abstraction or imagination. Of course, this is also the case in Keith's family in The Falling Man, which has already shattered. In the aftermath of 9-11, he returns 'home' in some sort of instinctive attempt to find where he is supposed to be - to put the world together again. The return 'home' is both the central and inciting action of the novel, the falling man's one response to the coming of the curse, the shattering of the world around him. It would have been easy and satisfying, perhaps, to make his effort successful - but what a different message, albeit a much simpler one! It is plausible, if idealistic, to think that tragedy might bring about a healing, a desire to draw close to those we love and to reconstitute society from its most basic unit. The problem with this is the artificiality of that unit and the attempt.

\section{THE MIRROR CRACK'D FROM SIDE TO SIDE: THE FAILURE OF STORYLINE}

In the Falling Man, Lianne runs a group for seniors in East Harlem who have early dementia. It is a writing group dedicated to producing "storylines". In Lianne's "storyline sessions", the group choose a topic and write about its significance in their lives, constructing a sort of loose but interconnected memoir, a narrative through which they can retain their connection to themselves and to others in their lives.

The storyline sessions exist as a counterpoint or foil to everything else that the story tells us about time, narrative and connection. Essentially, it is about the fracturing or failure of the storyline. Like the individuals with Alzheimer's (or, rather, to a greater degree than these individuals) the trauma of 9-11 knocks loose one's sense of one's story, of 
the linear world and one's place within it. This is perhaps why the narrative itself is disjointed and circular, with Keith ending at the same point in time that he started. Indeed, the idea of repetition is profound, both as a response to trauma and a (probably futile) charm against death.

Gilles Deleuze wrote extensively about repetition in 1968. Proposing that repetition is the counterpoint to 'generalization', he argues that, while the latter occurs in nature, for humans, repetition is inherently transgressive. Deleuze states that there are two forms of repetition: passive and active synthesis.

"Passive synthesis is exemplified by habit. Habit incarnates the past (and gestures to the future) in the present by transforming the weight of experience into an urgency. Habit creates a multitude of "larval selves," each of which functions like a small ego with desires and satisfactions.

"Active synthesis", on the other hand, consists of memory, which is "virtual and vertical.... It deals with events in their depth and structure rather than in their contiguity in time". To sustain his theories of repetition, Deleuze further states that there is no time but the present; the future and past being "... projections... created in the present" (Williams 19). The circular nature of the narrative in The Falling Man certainly seems to endorse this idea. The 'present' - the morning of the 9/11 terrorist attack - has sufficient power to call the character back to itself. Both beyond and in relation to that time, he truly is 'falling' - carried to a semblance of his past life, to his marriage. It fits the description of both more passive than active synthesis according to Deleuze. He returns to Lianne's home as though by instinct, thoughtlessly - a habit of mind, though one from eight years past. His habit of returning 'home' reconstitutes the past, for a time, within the present. Perhaps it even has the power to temporarily overcome the events of the present; but this is illusory, as he is called back to the moment of the terrorist attack at the end of the narrative.

One woman that Lianne works with, Rosellen, repeats and rephrases a single word, and Lianne understands this as being a sort of incantation for protection against a stark condition (Delillo TFM chapter 9). However, if repetition is a talisman of protection, or if it is, as psychology suggests, an optimised pattern, or if it is a habit, it is clear regardless that repetition is limiting, sequestering one from the onward movement of life. If it does protect, it does so by removing one from the fray and from the uncertainty of a life in which terrible events may occur. And thus removed, the subject lives an artificial life, a half-life, in which the connections, dangers and losses are all likewise abstract and provisional, one step removed from actual experience.

What effect, then, does this removal or detachment have on identity? It is immediately apparent that it may have a certain superficial advantage with regard to the individual's formation or continuation of identity, in that it becomes malleable - things become possible that would not otherwise be It is possible, for example, for Keith to step back seamlessly into the role of a husband - and then out of that role again. Repetition is permanent but fundamentally impermanent at the same time. As such, identity need not be committed to but can be endlessly recaptured or recreated. At the same time, just as the falling man has anonymity and is defined exclusively by what should be a fleeting action, Keith is gifted with a similar anonymity several times in the narrative when described through the eyes of others.

If the forging of identity in the story represents that which exists for Americans post-9/11, we can see it as being similarly transitive, non-committal, and continuously pulled back toward the moment of tragedy and loss. The falling man, after all, has no potential at all (for he will die on impact with the ground) but as long as he remains falling rather than already fallen, he is protected from the death that he has, in desperation, chosen. Thus, perhaps, Americans, under threat, existed in an in-between identity in which both moving ahead constructively and surrendering are similarly impossible. This limbo or in-between status has another effect - as Rosellen finds, while trying to write a story but becoming mired in repetition, storyline collapses. A linear narrative curve is almost impossible to navigate and create when elements of the story repeat, as though obsessively, and one cannot move past this repetition to a climax and conclusion.

\section{THE JOURNEY}

The breaking down of plot or storyline that is found in Delillo's two novels as well as Tennyson's poem is made all the more evident by the overt echoes of a hero's journey or quest in the novels, and, in most cases, their failure. One could argue, for example, that the Lady of Shalott does leave her tower to undertake a journey, the obvious flaw being, of course, that she uneventfully dies before she reaches her destination. Her journey is only to her own doom, or her own funeral; Lancelot's faint and detached acknowledgment of her being a final, ironic blow. In The Falling Man, Keith undertakes a journey, and one that, like the hero's journey, is circular. His call to adventure comes when, after witnessing the collapse of the Twin Towers, he goes 'home'. However, discovering there only a 'shadow' or a fragmented, insubstantial repetition of the home he has left, his journey becomes circular and repetitive, and he ends at the point he began - nothing accomplished, healed or resolved.

In White Noise, however, there is at the very conclusion a journey that is, in embryonic form, a hero's journey. It represents true movement and leaving the norm in order to face challenges; it renders the society left behind richer, as it brings about hope. Wilder, the youngest child of Jack and Babette, rides his tricycle across the highway and miraculously survives. He dodges the cruel fate that Jack and Babette fear for him and themselves throughout the narrative, and the novel concludes with this story of survival. If the central theme and conflict of White Noise is the existential dread that precedes and foresees disaster, then the deux ex machina that may resolve it is the image of the toddler, Wilder, at the conclusion of the novel, riding a tricycle across the highway and emerging unscathed. Indeed, Wilder's feat is the culmination of the many fears of his mother that the will be killed, and is, even at face value, a remarkable (or remarkably lucky) event. But what else does it represent? 
Wilder is the smallest and most vulnerable member of the family, and therefore the one on whom many fears are pinned. His tricycle is the smallest and most precarious vehicle imaginable, human (child)-powered and unequipped to carry him across the rapid, unfeeling and deadly machine of American life, the highway that is the lifeline of industry and transport of goods, any element of which at any moment could annihilate the fragile boy. And yet, in this story, it cannot, or at least does not. For who is Wilder? His name evokes imagery intimately involved with American identity - the wild, the wilderness, perhaps the Wild West. If an adjective, it is a comparative form - wilder than... whom? Or what? Any other character in the family and the narrative, apparently. Wilder is the wild card, the one who is frequently disappearing, who in this final scene accomplishes a feat no one would have predicted - not merely surviving with this own life, but restoring some of the hope that his family lacks.

It is perhaps noteworthy that Wilder is also the surname of an iconic American writer, Laura Ingalls Wilder, who wrote the story of her family's pioneering journey west during the Frontier era. Like Wilder, her family survived considerable odds, elements that could have been expected to annihilate them, in a small, self-propelling vehicle. This was the Ingalls family of Little House on the Prairie fame, and surely their covered wagon traversing hundreds of miles of unsettled land serves as some sort of macrocosm of Wilder's trek across the highway.

If one knows the Ingalls' (Wilders') story at all, one knows that it was a triumph of hope over failure, of the kind that, perhaps stereotypically, was thought to epitomize America. Perhaps Wilder represents the small continuation of these values and the valour that characterizes them, or the idea that something small and unafraid can survive the onslaught of something large and inexorable. Watching Wilder's trek, Jack and Babette are confronted by a genuine threat, in contrast to the vague feeling of doom they had previously and perpetually grappled with. There is the real possibility that this will prove a step too far, that their sense of doom or of having been cursed will be fulfilled, and that Wilder's own journey will be short and meaningless, much like the Lady of Shalott floating down to Camelot, singing "her last song".

Instead, there is grace and luck. Wilder makes it across the road and into his own uncertain future, and in doing so, perhaps he brings back to his family a sense of relief, genuine connection, and most importantly, hope.

\section{CONCLUSION}

With the single exception of the toddler Wilder, making his linear way into the path of authentic danger and surviving, Delillo's two novels are a powerful rendition of a falling state. In this state, real catastrophes may work as catalysts, but are not ultimately responsible for the devastation that makes up the characters' mental and psychological landscape. The internal devastation is, indeed, crippling and damning. Characters struggle for but fail to attain an authentic connection with one another, settling instead for simulated versions of the social and cultural landscape. The sense of loss that stems from this lack of authenticity is its both its result and its driving force. It seems, from the stories, that the outlook on humanity is ultimately pessimistic; once connection is lost, it is always sought but never regained. In this way, Delillo's imagining of humans in the modern era is indeed descriptive of a fall from grace in the manner of the Garden of Eden; after the Fall, death is inevitable, and the constant and unthinking connection with the divine is lost. All that follows is an attempt to regain what has been lost, and that attempt, in this life, is in vain. By the same token, everything that comes after the Fall is a less authentic version of existence, a copy. It is no wonder then that the characters feel as though there is a barrier between them and true reality, just like shadows of the world that appear to the Lady of Shalott.

In this falling state, everything is breaking down - for a start, the characters' connection to themselves, the past and the future. Curses threaten their sense of a future, while the past is made into a parody of itself. Their ability to act as part of a coherent narrative and to undertake a fruitful journey is impaired. This appears to demonstrate how completely these abilities depend upon that same central sense of connection with one another, the larger society surrounding us, our past and our future. Isolation stemming from fear of a curse is indeed a curse itself, blighting existence, however much or little it is borne out in fact.

\section{END NOTES}

1. The Courtly Love tradition was established in the West by Dante, who, catching a single glimpse of Beatrice from across a courtyard, falls instantly in love and spends years pursuing her; this is described in his poem "Vita Nuova"

2, T.S. Eliot, "The Hollow Men"

3. "He tried to tell himself he was alive, but the idea was too obscure to take hold" (Delillo TFM p. 6)

\section{REFERENCES}

Alaya, Flavia M. "Tennyson's 'The Lady of Shalottt': The Triumph of Art". Victorian Poetry Vol. 8 (No. 4) Winter 1970 , pp. $273-289$

Brown, Brene. "The Price of Invulnerability". transcriptvids. com/v/UoM. Uploaded by TedxTalks on 12.10.2010

Deleuze, Gilles Difference and Repetition Presses Universitaires de France, 1968 and New York: Columbia University Press (Translated by Paul R. Patton), 1994.

Delillo, Don. White Noise. New York: Viking Press, 1985.

Delillo, Don. The Falling Man. New York: Scribner, 2007.

Descartes, Rene. Meditations on First Philosophy (1641)

Litt, Toby. "The Trembling Air". The Guardian May 262007

"Nuclear Protection". Nuclear, Biological, Chemical Protection Field Manual (FM 3-4). Washington, DC: US Department of Defense 21 February 1996 Archived from the original on 13 March 2013

Woodward, Aylin. "Alexandria Ocasio-Cortez wonders whether people should have kids in a climate-ravaged world. So does this movement of 'BirthStrikers"' Business Insider March 232019 businessinsider.com 
van der Kolk, Bessel. "The Compulsion to Repeat Trauma: Revictimization, Attachment and Masochism". Psychiatric Clinics of North America 12 (1989) 389-411

van der Kolk, Bessel. The Body Keeps Score: Brain, Mind and Body in the Healing of Trauma. New York: Viking Penguin, 2015
Vonnegut, Kurt. Slaughterhouse Five. Delacorte, 1969.

Wall, Mike. "We're probably living in a simulation, Elon Musk says." Sept 72018 space.com

Williams, James. Gilles Deleuze's Philosophy of Time. Edinburgh: Edinburgh University Press, 2011

\section{APPENDIX 1}

\section{THE LADY OF SHALOTT BY ALFRED, LORD TENNYSON}

\section{Part I}

On either side the river lie

Long fields of barley and of rye,

That clothe the wold and meet the sky;

And thro' the field the road runs by

To many-tower'd Camelot;

The yellow-leaved waterlily

The green-sheathed daffodilly

Tremble in the water chilly

Round about Shalott.

Willows whiten, aspens shiver.

The sunbeam showers break and quiver

In the stream that runneth ever

By the island in the river

Flowing down to Camelot.

Four gray walls, and four gray towers

Overlook a space of flowers,

And the silent isle imbowers

The Lady of Shalott.

Underneath the bearded barley,

The reaper, reaping late and early,

Hears her ever chanting cheerly,

Like an angel, singing clearly,

O'er the stream of Camelot.

Piling the sheaves in furrows airy,

Beneath the moon, the reaper weary

Listening whispers, " 'Tis the fairy,

Lady of Shalott.'

The little isle is all inrail'd

With a rose-fence, and overtrail'd

With roses: by the marge unhail'd

The shallop flitteth silken sail'd,

Skimming down to Camelot.

A pearl garland winds her head:

She leaneth on a velvet bed,

Full royally apparelled,

The Lady of Shalott.

\section{Part II}

No time hath she to sport and play: A charmed web she weaves alway.
A curse is on her, if she stay

Her weaving, either night or day,

To look down to Camelot.

She knows not what the curse may be;

Therefore she weaveth steadily,

Therefore no other care hath she,

The Lady of Shalott.

She lives with little joy or fear.

Over the water, running near,

The sheepbell tinkles in her ear.

Before her hangs a mirror clear,

Reflecting tower'd Camelot.

And as the mazy web she whirls,

She sees the surly village churls,

And the red cloaks of market girls

Pass onward from Shalott.

Sometimes a troop of damsels glad,

An abbot on an ambling pad,

Sometimes a curly shepherd lad,

Or long-hair'd page in crimson clad,

Goes by to tower'd Camelot:

And sometimes thro' the mirror blue

The knights come riding two and two:

She hath no loyal knight and true,

The Lady of Shalott.

But in her web she still delights

To weave the mirror's magic sights,

For often thro' the silent nights

A funeral, with plumes and lights

And music, came from Camelot:

Or when the moon was overhead

Came two young lovers lately wed;

'I am half sick of shadows,' said

The Lady of Shalott.

\section{Part III}

A bow-shot from her bower-eaves, He rode between the barley-sheaves, The sun came dazzling thro' the leaves, And flam'd upon the brazen greaves

Of bold Sir Lancelot.

A red-cross knight for ever kneel'd

To a lady in his shield, 
That sparkled on the yellow field, Beside remote Shalott.

The gemmy bridle glitter'd free,

Like to some branch of stars we see

Hung in the golden Galaxy.

The bridle bells rang merrily

As he rode down from Camelot:

And from his blazon'd baldric slung

A mighty silver bugle hung,

And as he rode his armour rung,

Beside remote Shalott.

All in the blue unclouded weather

Thick-jewell'd shone the saddle-leather,

The helmet and the helmet-feather

Burn'd like one burning flame together,

As he rode down from Camelot.

As often thro' the purple night,

Below the starry clusters bright,

Some bearded meteor, trailing light,

Moves over green Shalott.

His broad clear brow in sunlight glow'd;

On burnish'd hooves his war-horse trode;

From underneath his helmet flow'd

His coal-black curls as on he rode,

As he rode down from Camelot.

From the bank and from the river

He flash'd into the crystal mirror,

'Tirra lirra, tirra lirra:'

Sang Sir Lancelot.

She left the web, she left the loom

She made three paces thro' the room

She saw the water-flower bloom,

She saw the helmet and the plume,

She look'd down to Camelot.

Out flew the web and floated wide;

The mirror crack'd from side to side;

'The curse is come upon me,' cried

The Lady of Shalott.

\section{Part IV}

In the stormy east-wind straining,

The pale yellow woods were waning,

The broad stream in his banks complaining,

Heavily the low sky raining

Over tower'd Camelot;

Outside the isle a shallow boat

Beneath a willow lay afloat,

Below the carven stern she wrote,

The Lady of Shalott.

A cloudwhite crown of pearl she dight,

All raimented in snowy white
That loosely flew (her zone in sight

Clasp'd with one blinding diamond bright)

Her wide eyes fix'd on Camelot,

Though the squally east-wind keenly

Blew, with folded arms serenely

By the water stood the queenly

Lady of Shalott.

With a steady stony glance-

Like some bold seer in a trance,

Beholding all his own mischance,

Mute, with a glassy countenance-

She look'd down to Camelot.

It was the closing of the day:

She loos'd the chain, and down she lay;

The broad stream bore her far away,

The Lady of Shalott.

As when to sailors while they roam, By creeks and outfalls far from home,

Rising and dropping with the foam,

From dying swans wild warblings come,

Blown shoreward; so to Camelot

Still as the boathead wound along

The willowy hills and fields among,

They heard her chanting her deathsong,

The Lady of Shalott.

A longdrawn carol, mournful, holy,

She chanted loudly, chanted lowly,

Till her eyes were darken'd wholly,

And her smooth face sharpen'd slowly,

Turn'd to tower'd Camelot:

For ere she reach'd upon the tide

The first house by the water-side,

Singing in her song she died,

The Lady of Shalott.

Under tower and balcony,

By garden wall and gallery,

A pale, pale corpse she floated by,

Deadcold, between the houses high,

Dead into tower'd Camelot.

Knight and burgher, lord and dame,

To the planked wharfage came:

Below the stern they read her name, The Lady of Shalott.

They cross'd themselves, their stars they blest, Knight, minstrel, abbot, squire, and guest.

There lay a parchment on her breast,

That puzzled more than all the rest,

The wellfed wits at Camelot.

'The web was woven curiously,

The charm is broken utterly,

Draw near and fear not,- - this is I,

The Lady of Shalott.' 